\title{
Formation of Hydroxyapatite on Ti-Coated Ti-Zr-Cu-Pd Bulk Metallic Glass
}

\author{
F. X. Qin*, X. M. Wang, T. Wada, G. Q. Xie, K. Asami and A. Inoue \\ Institute for Materials Research, Tohoku University, Sendai 980-8577, Japan
}

In this research, Ti coating was conducted on $\mathrm{Ti}_{40} \mathrm{Zr}_{10} \mathrm{Cu}_{36} \mathrm{Pd}_{14}$ bulk metallic glass (BMG) in order to increase the formation rate of hydroxyapatite layer. The formation behavior of bone-like hydroxyapatite on Ti-coated and uncoated $\mathrm{Ti}_{40} \mathrm{Zr}_{10} \mathrm{Cu}_{36} \mathrm{Pd}_{14}$ bulk metallic glasses (BMGs) was studied. The surface morphology of Ti-coated and uncoated $\mathrm{Ti}_{40} \mathrm{Zr}_{10} \mathrm{Cu}_{36} \mathrm{Pd}_{14}$ BMG was investigated by scanning electron microscopy and energy dispersive X-ray spectroscopy. The results revealed that the alkali pretreatment in $5 \mathrm{M} \mathrm{NaOH}$ solution at $60^{\circ} \mathrm{C}$ for $24 \mathrm{~h}$ had a beneficial effect on the formation of porous sodium titanate on Ti-coated $\mathrm{Ti}_{40} \mathrm{Zr}_{10} \mathrm{Cu}_{36} \mathrm{Pd}_{14}$ BMG. A bone-like hydroxyapatite layer was able to form on the alkali-treated Ti-coated $\mathrm{Ti}_{40} \mathrm{Zr}_{10} \mathrm{Cu}_{36} \mathrm{Pd}_{14} \mathrm{BMG}$ after a short-time immersion in simulated body fluid (SBF). On the contrary, hydroxyapatite formation was not observed on the uncoated $\mathrm{Ti}_{40} \mathrm{Zr}_{10} \mathrm{Cu}_{36} \mathrm{Pd}_{14} \mathrm{BMG}$ after the same chemical treatments. [doi:10.2320/matertrans.MRA2008221]

(Received July 18, 2008; Accepted January 6, 2009; Published February 18, 2009)

Keywords: titanium, bulk metallic glass, sputter-coating, hydroxyapatite, biomedical applications

\section{Introduction}

Ti-based bulk metallic glasses (BMGs) have an attractive potential to be applied as biomaterials due to their high corrosion resistance, excellent mechanical properties and good biocompatibility. ${ }^{1)}$ Recently, Ni-free Ti-Zr-Cu-Pd BMGs and their composites with high glass-forming abilities exhibiting high strength and good corrosion resistance have been developed. ${ }^{2-4)}$ It is well known that the bioactivity of metallic implants are usually evaluated by the nucleation and growth of hydroxyapatite. However, recent results have shown that apatite cannot form directly on an alkali-treated Ti-based BMG. In order to combine the excellent mechanical advantages of Ti-based BMGs with the good bioactivity of pure titanium, the Ti coating is regarded as a possible way to achieve. Sputter-coatings are effective in improving the surface properties of metallic materials, including wear resistance, anti-corrosion properties and oxidation resistance. ${ }^{5-7)} \mathrm{Ti}$ is a good biocompatible material and has good corrosion resistance even in $\mathrm{Cl}^{-}$containing solutions. It is expected that Ti-containing coating can improve the corrosion resistance and apatiteforming ability of Ti-Zr-Cu-Pd BMG. It has been reported that a TiN sputter-coating on Ti-6Al-4V alloy enhances wear resistance and corrosion performance in artificial hip joints. ${ }^{8)}$ Magnetron sputtering coating is not yet applied on BMGs. Therefore, the application of magnetron sputtercoating to BMGs materials is a totally new topic facing for all materials researchers. In our previous work, authors found that the proper chemical treatments applied on Ticoated $\mathrm{Zr}_{55} \mathrm{Al}_{10} \mathrm{Ni}_{5} \mathrm{Cu}_{30}$ BMG dramatically enhance the nucleation and growth of bone-like hydroxyapatite layer in SBF. ${ }^{9)}$ The alkaline pretreatment is possible to change the initial surface of Ti-coated BMGs into a favorable state for the hydroxyapatite formation. The purpose of the present study are to investigate the formation behavior of hydroxyapatite on uncoated and Ti-coated $\mathrm{Ti}_{40} \mathrm{Zr}_{10} \mathrm{Cu}_{36} \mathrm{Pd}_{14} \mathrm{BMG}$,

*Corresponding author, E-mail: fxqin@imr.tohoku.ac.jp to accelerate the hydroxyapatite formation on Ti-coated $\mathrm{Ti}_{40} \mathrm{Zr}_{10} \mathrm{Cu}_{36} \mathrm{Pd}_{14} \mathrm{BMG}$ through the alkaline pretreatment.

\section{Experimental Procedure}

An alloy with a nominal composition of $\mathrm{Ti}_{40} \mathrm{Zr}_{10} \mathrm{Cu}_{36} \mathrm{Pd}_{14}$ was prepared by arc-melting the mixture of pure metals (>99.9 mass\%) in an argon atmosphere. The BMG samples, in a rod form with a diameter of $4 \mathrm{~mm}$, were prepared by injection-casting into a copper mold. The rod sample was then cut to 1-mm-thick slices. The slice sample was polished with $\mathrm{SiC}$ paper up to $1000 \#$. Before the magnetic sputtering was performed, $\mathrm{Ti}_{40} \mathrm{Zr}_{10} \mathrm{Cu}_{36} \mathrm{Pd}_{14} \mathrm{BMG}$ was finely polished with $\mathrm{SiC}$ paper and $\mathrm{Al}_{2} \mathrm{O}_{3}$ paste, then ultrasonically washed in distilled water and acetone, and finally dried in hot air. Afterwards, $\mathrm{Ti}$ was coated on a $\mathrm{Ti}_{40} \mathrm{Zr}_{10} \mathrm{Cu}_{36} \mathrm{Pd}_{14}$ plate by magnetron-sputtering of pure $\mathrm{Ti}$ metal cathode in a nitrogen protective atmosphere at $200^{\circ} \mathrm{C}$ using the D. C. magnetronsputtering equipment.

$\mathrm{Ti}_{40} \mathrm{Zr}_{10} \mathrm{Cu}_{36} \mathrm{Pd}_{14}$ BMG and Ti-coated $\mathrm{Ti}_{40} \mathrm{Zr}_{10} \mathrm{Cu}_{36} \mathrm{Pd}_{14}$ BMG samples were etched in $5 \% \mathrm{HCl}+30 \% \mathrm{HNO}_{3}$ for $10 \mathrm{~s}$ at room temperature. The purpose of an acidic treatment is to increate the roughness of the initial surface and the thickness of the titanium oxide. The samples were then treated in $5 \mathrm{M} \mathrm{NaOH}$ solution at $60^{\circ} \mathrm{C}$ for $24 \mathrm{~h}$. To remove the remaining alkali, the samples were ultrasonically cleaned for $5 \mathrm{~min}$ and then dried. Finally, the pretreated samples were immersed in SBF, the chemical composition of which $(\mathrm{g} / \mathrm{L})$ is $8.00 \mathrm{NaCl}, 0.40 \mathrm{KCl}, 0.35 \mathrm{NaHCO}_{3}, 0.19$ $\mathrm{CaCl}_{2} \cdot 2 \mathrm{H}_{2} \mathrm{O}, 0.09 \mathrm{Na}_{2} \mathrm{HPO}_{4} \cdot 7 \mathrm{H}_{2} \mathrm{O}, 0.20 \quad \mathrm{MgSO}_{4} \cdot 7 \mathrm{H}_{2} \mathrm{O}$, $0.06 \mathrm{KH}_{2} \mathrm{PO}_{4}$, and 1.00 Glucose. The mmorphology of the sample surface was observed by scanning electron microscopy (SEM; Hitachi S-4800). The chemical information of sample surface after the alkaline pretreatment and the immersion in SBF was investigated by X-ray energy dispersive spectroscopy (EDS). The structure of the treated samples after immersion in Hanks' solution was examined by micro-area X-ray diffraction with Co K $\alpha$ radiation (XRD, Bruker, D 8 Discover GADDS). 

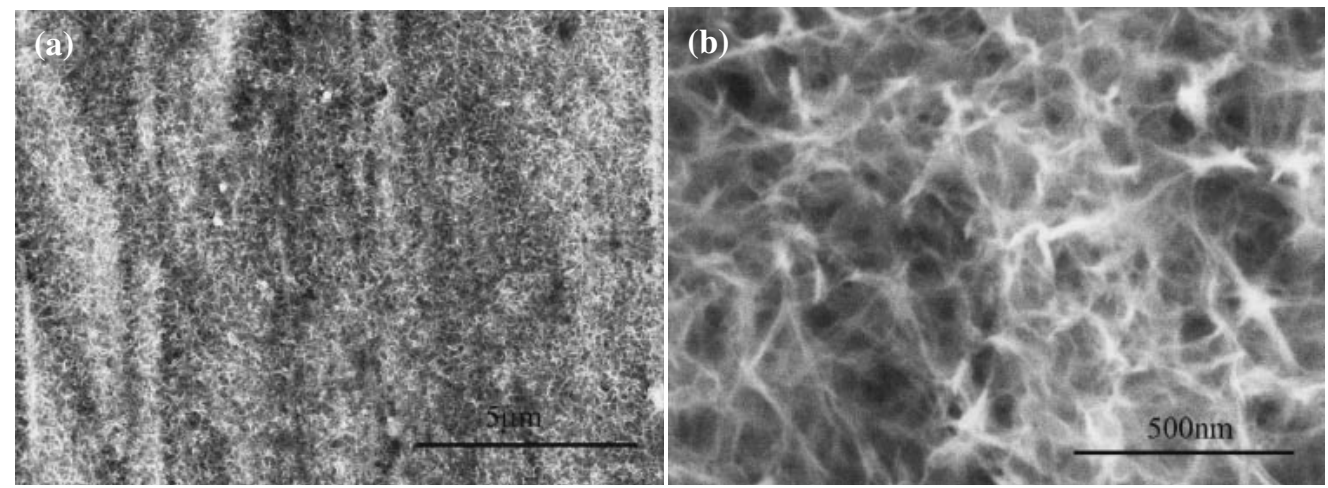

Fig. 1 Surface morphologies of Ti-based $\mathrm{Ti}_{40} \mathrm{Zr}_{10} \mathrm{Cu}_{36} \mathrm{Pd}_{14} \mathrm{BMG}$ after $5 \mathrm{M} \mathrm{NaOH}$ treatment at $60^{\circ} \mathrm{C}$ for $24 \mathrm{~h}$ (a) low magnification (b) high magnification.

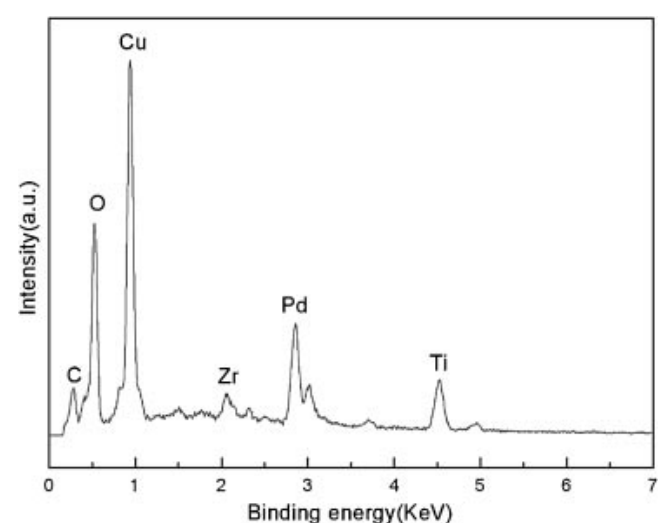

Fig. 2 EDS spectrum (accelerated voltage of $15 \mathrm{kV}$ ) of $\mathrm{Ti}_{40} \mathrm{Zr}_{10} \mathrm{Cu}_{36} \mathrm{Pd}_{14}$ BMG after $5 \mathrm{M} \mathrm{NaOH}$ treatment at $60^{\circ} \mathrm{C}$ for $24 \mathrm{~h}$.

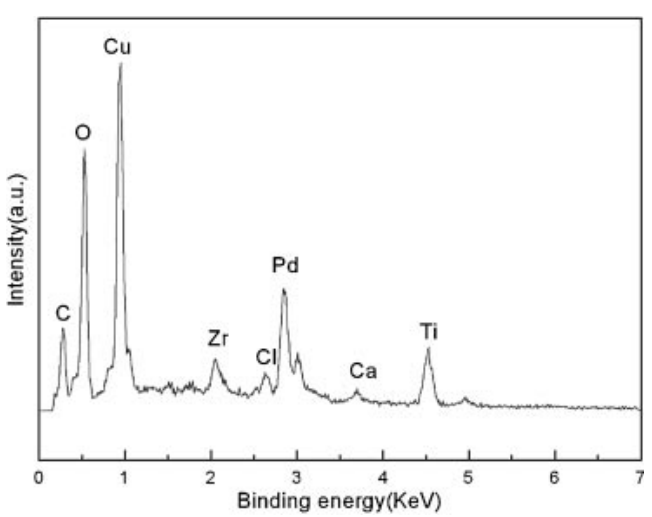

Fig. 4 EDS spectrum (accelerated voltage of $15 \mathrm{kV}$ ) of alkali-treated $\mathrm{Ti}_{40} \mathrm{Zr}_{10} \mathrm{Cu}_{36} \mathrm{Pd}_{14} \mathrm{BMG}$ immersed in Hanks' solution for 15 days.
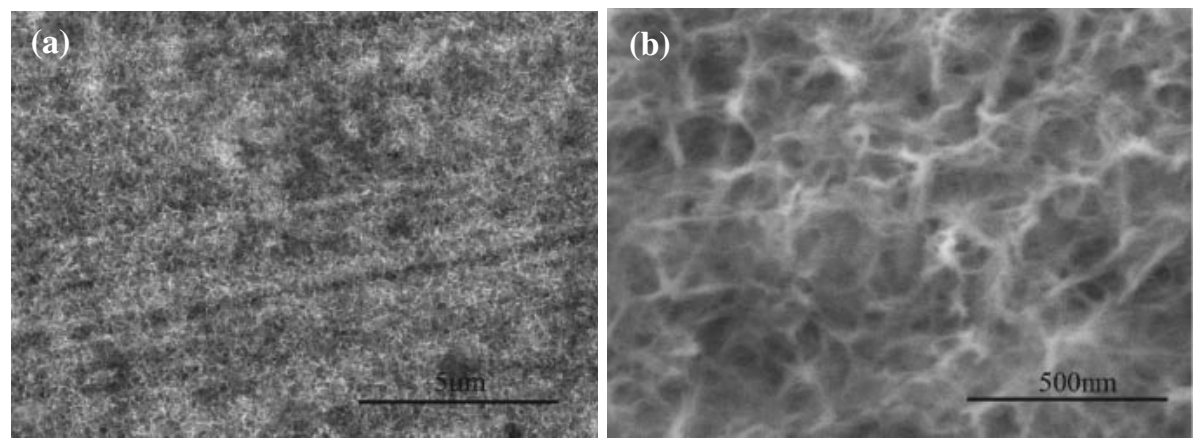

Fig. 3 Surface morphologies of alkali-treated $\mathrm{Ti}_{40} \mathrm{Zr}_{10} \mathrm{Cu}_{36} \mathrm{Pd}_{14}$ BMG immersed in Hanks' solution for 15 days (a) low magnification (b) high magnification.

\section{Results and Discussion}

The surface morphologies of $\mathrm{Ti}_{40} \mathrm{Zr}_{10} \mathrm{Cu}_{36} \mathrm{Pd}_{14} \mathrm{BMG}$ and Ti-coated $\mathrm{Ti}_{40} \mathrm{Zr}_{10} \mathrm{Cu}_{36} \mathrm{Pd}_{14}$ BMG treated in $5 \mathrm{M} \mathrm{NaOH}$ solution at $60 \mathrm{C}$ for $24 \mathrm{~h}$ are shown in Fig. 1 and Fig. 3, respectively. As shown in Fig. 1, a porous structure is formed on the surface of $\mathrm{Ti}_{40} \mathrm{Zr}_{10} \mathrm{Cu}_{36} \mathrm{Pd}_{14} \mathrm{BMG}$, which attested the alkaline treatment efficiently increase the surface roughness. The EDS spectra exhibit the peaks of $\mathrm{C}, \mathrm{O}, \mathrm{Cu}, \mathrm{Zr}, \mathrm{Pd}$, and $\mathrm{Ti}$ elements (Fig. 2). It is clear seen that the surface is mainly composed of $\mathrm{Cu}$ and $\mathrm{Pd}$. The peak of $\mathrm{C}$ is assigned to the residue contaminants on the top surface of the specimens. Furthermore, no peak of sodium was detected on the surface, indicating that no sodium titanate had formed on the uncoated $\mathrm{Ti}_{40} \mathrm{Zr}_{10} \mathrm{Cu}_{36} \mathrm{Pd}_{14} \mathrm{BMG}$ after the alkali treatment. The surface morphology of pre-treated $\mathrm{Ti}_{40} \mathrm{Zr}_{10} \mathrm{Cu}_{36} \mathrm{Pd}_{14}$ BMG after a 15 -day immersion in SBF remains a porous state, and the hydroxyapatite doesnot form as shown in Fig. 3. The EDS result shown in Fig. 4 exhibits that small amounts of $\mathrm{Cl}$ and $\mathrm{Ca}$ besides $\mathrm{C}, \mathrm{O}, \mathrm{Cu}, \mathrm{Zr}, \mathrm{Pd}$, and $\mathrm{Ti}$, are also detected, which maybe contributed to the chemical deposition from the SBF. From above shown results, the alkaline treatment on $\mathrm{Ti}_{40} \mathrm{Zr}_{10} \mathrm{Cu}_{36} \mathrm{Pd}_{14}$ BMG change the surface state to a porous state, however, it cannot play a beneficial role on the formation of hydroxyapatite on $\mathrm{Ti}_{40} \mathrm{Zr}_{10} \mathrm{Cu}_{36} \mathrm{Pd}_{14}$ BMG. 

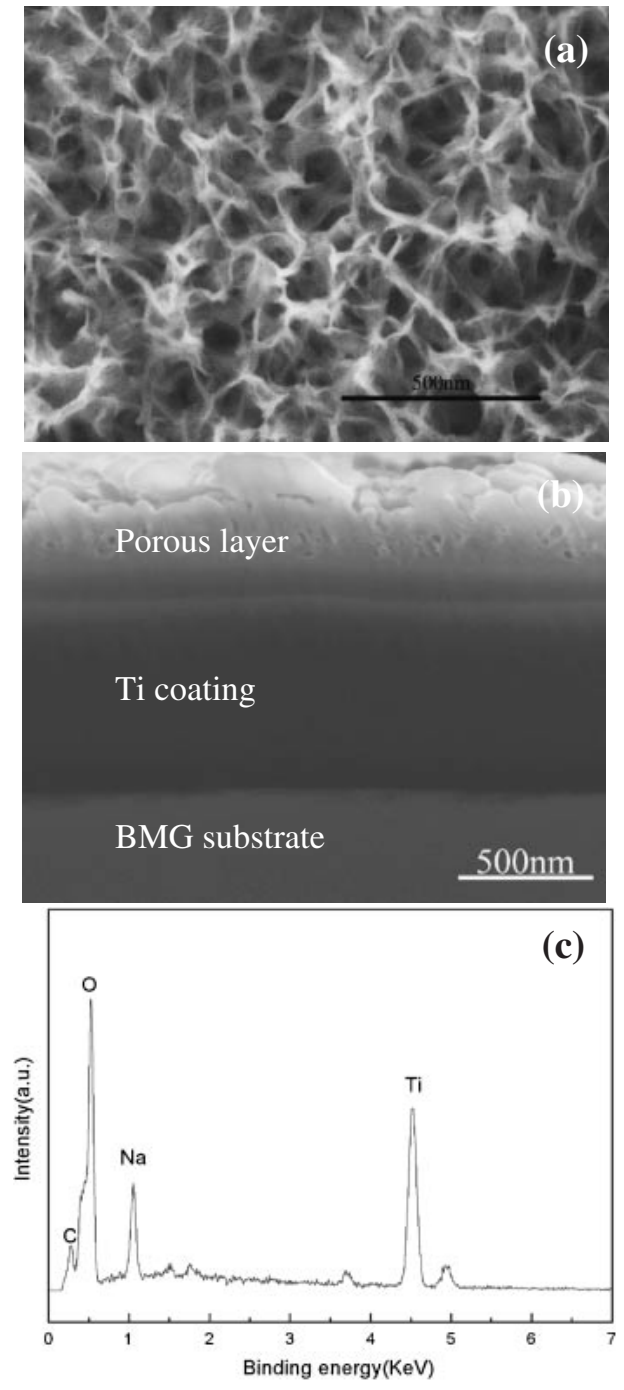

Fig. 5 Surface morphology (a), cross-section morphology (b) and EDS spectrum (c) of Ti-coated $\mathrm{Ti}_{40} \mathrm{Zr}_{10} \mathrm{Cu}_{36} \mathrm{Pd}_{14}$ BMG after $5 \mathrm{M} \mathrm{NaOH}$ treatment at $60^{\circ} \mathrm{C}$ for $24 \mathrm{~h}$.

To resolve the problem of low apatite formation on $\mathrm{Ti}_{40} \mathrm{Zr}_{10} \mathrm{Cu}_{36} \mathrm{Pd}_{14} \mathrm{BMG}$, pure Ti was sputtered onto $\mathrm{Ti}_{40} \mathrm{Zr}_{10^{-}}$ $\mathrm{Cu}_{36} \mathrm{Pd}_{14}$ BMG. A porous and network layer with a thickness of about $300 \mathrm{~nm}$, confirmed by SEM cross-section observation, is achieved on the Ti-coated $\mathrm{Ti}_{40} \mathrm{Zr}_{10} \mathrm{Cu}_{36} \mathrm{Pd}_{14} \mathrm{BMG}$ after the same treatments as that on the bare BMG, as shown in Fig. 5(a) and (b). The EDS results presented in Fig. 5(c), proved that the porous layer formed in $\mathrm{NaOH}$ solution is a sort of a compound mainly consisting of $\mathrm{Na}$, $\mathrm{Ti}$ and $\mathrm{O}$. In addition, a small peak at $3.7 \mathrm{keV}$ is identified as a potassium impurity which exists in $\mathrm{NaOH}$ solution. The most possible compound corresponding to EDS result should be a sodium titanate phase. The sodium titanate hydrogel layer was formed on the Ti-coated $\mathrm{Ti}_{40} \mathrm{Zr}_{10} \mathrm{Cu}_{36} \mathrm{Pd}_{14}$ BMG due to the reaction between $\mathrm{Ti}$ coating layer and the alkali solution. A sodium titanate hydrogel layer, which is beneficial to the formation of hydroxyapatite, will typically form on the surface of $\mathrm{Ti}$ alloys after an alkali treatment. The alkali pretreated $\mathrm{Ti}_{40} \mathrm{Zr}_{10} \mathrm{Cu}_{36} \mathrm{Pd}_{14} \mathrm{BMG}$ was immersed in $\mathrm{SBF}$, and the formation of hydroxyapatite layer was expected due to the presence of sodium titanate interlayer. In order to monitor the nucleation and growth of the hydroxyapatite layer on $\mathrm{Ti}_{40} \mathrm{Zr}_{10} \mathrm{Cu}_{36} \mathrm{Pd}_{14} \mathrm{BMG}$, the samples were taken out after immersion for 1 day, 3 days, 6 days and 15 days. The surface morphologies of the alkaline pretreated Ti-coated $\mathrm{Ti}_{40} \mathrm{Zr}_{10} \mathrm{Cu}_{36} \mathrm{Pd}_{14}$ BMG immersed in SBF for the different time period are shown in Fig. 6. After the samples are immersed only for one day, a few white nuclei are observed (Fig. 6(a)), demonstrating that the initiation of nucleation was fulfilled within a short immersion time. With an increase of the immersion time, the particles gradually proliferated and spread all over the surface during a 15-day immersion, as shown in Fig. 6(b), (c) and (d). The corresponding EDS results in Fig. 7 show that the particles are rich in $\mathrm{Ca}$ and $\mathrm{P}$, with the $\mathrm{Ca} / \mathrm{P}$ ratio being 1.67 , which is consistence with the composition of hydroxyapatite. A few cracks appear in the layer after a 15-day immersion because of the contracting force occurs when the hydrated surface dries. ${ }^{10)} \mathrm{X}$-ray mappings also present the tracking of $\mathrm{C}, \mathrm{O}, \mathrm{Ca}, \mathrm{P}$, and $\mathrm{Ti}$ in Fig. 8, where Ti originates from the primary surface along the cracks. Figure 9 shows the SEM cross-section morphology of Ti-coated $\mathrm{Ti}_{40} \mathrm{Zr}_{10} \mathrm{Cu}_{36} \mathrm{Pd}_{14}$ BMG after a 15-day immersion in SBF. The thickness of calcium phosphate layer is about $300 \mathrm{~nm}$. It is clear that the porous hydroxyapatite shows good bonding with the previously alkali-treated layer. The XRD pattern of the surface of the Ti-coated $\mathrm{Ti}_{40} \mathrm{Zr}_{10^{-}}$ $\mathrm{Cu}_{36} \mathrm{Pd}_{14}$ metallic glass after immersion in SBF for 15 days is shown in Fig. 10. The characteristic peaks arising from hydroxyapatite as well as some peaks from $\alpha$-Ti are identified.

In this study, to increase bioactivity, pure Ti was coated on $\mathrm{Ti}_{40} \mathrm{Zr}_{10} \mathrm{Cu}_{36} \mathrm{Pd}_{14}$ BMG. A subsequent alkali treatment followed by immersion in SBF was applied to the Ti-coated BMG and uncoated BMG. The formation of hydroxyapatite is normally used to evaluate the bioactivity of metallic implants, because apatite is chemically similar to the mineral components of bones, thus supporting bone ingrowths. ${ }^{11-19)}$ A simple chemical and thermal two-step treatment method has been widely used, because the bone-like apatite can form in biomimetic solutions, which can be realized on the conventional alloys. ${ }^{11,12)}$ Accordingly, the two-step chemical treatment method is chosen to be applied on $\mathrm{Ti}_{40} \mathrm{Zr}_{10^{-}}$ $\mathrm{Cu}_{36} \mathrm{Pd}_{14}$ and Ti-coated $\mathrm{Ti}_{40} \mathrm{Zr}_{10} \mathrm{Cu}_{36} \mathrm{Pd}_{14}$ BMGs to investigate the formation of bone-like hydroxyapatite. As above mentioned, no apatite was formed on the surface of the alkali-pretreated $\mathrm{Ti}_{40} \mathrm{Zr}_{10} \mathrm{Cu}_{36} \mathrm{Pd}_{14} \mathrm{BMG}$ even after a long period of immersion in SBF. As shown in the EDS results in Fig. 2, no sodium titanate was formed on the surface of the Ti-based BMG; consequently, an apatite layer cannot form on the surface of the pretreated Ti-based BMG, even after a 15-day immersion in SBF. Although Ti metal has a strong ability to form apatite in SBF after being pretreated with aqueous $\mathrm{NaOH},{ }^{11-14)}$ the concentration of $\mathrm{Ti}$ in this alloy is rather low, i.e., only $40 \%$. Furthermore, $\mathrm{Zr}$ metal has only a very low apatite-forming ability, which is attributed to the lack of $\mathrm{Na}$ ion on the surface of $\mathrm{NaOH}$-treated $\mathrm{Zr}$ metal. ${ }^{20)} \mathrm{In}$ addition, no apatite-forming ability was reported in the other metals $(\mathrm{Cu}$ and $\mathrm{Pd})$ of this alloy. As shown in Fig. 2, the main elements are $\mathrm{Cu}$ and $\mathrm{Pd}$ on the surface of $\mathrm{Ti}_{40} \mathrm{Zr}_{10^{-}}$ $\mathrm{Cu}_{36} \mathrm{Pd}_{14} \mathrm{Ti}$-based BMG after acidic and alkaline treatments. Therefore, the apatite-forming ability of $\mathrm{Ti}_{40} \mathrm{Zr}_{10} \mathrm{Cu}_{36} \mathrm{Pd}_{14}$ $\mathrm{BMG}$ is rather low, even after pretreatment with alkali solution and a subsequence 15-day immersion in SBF. 

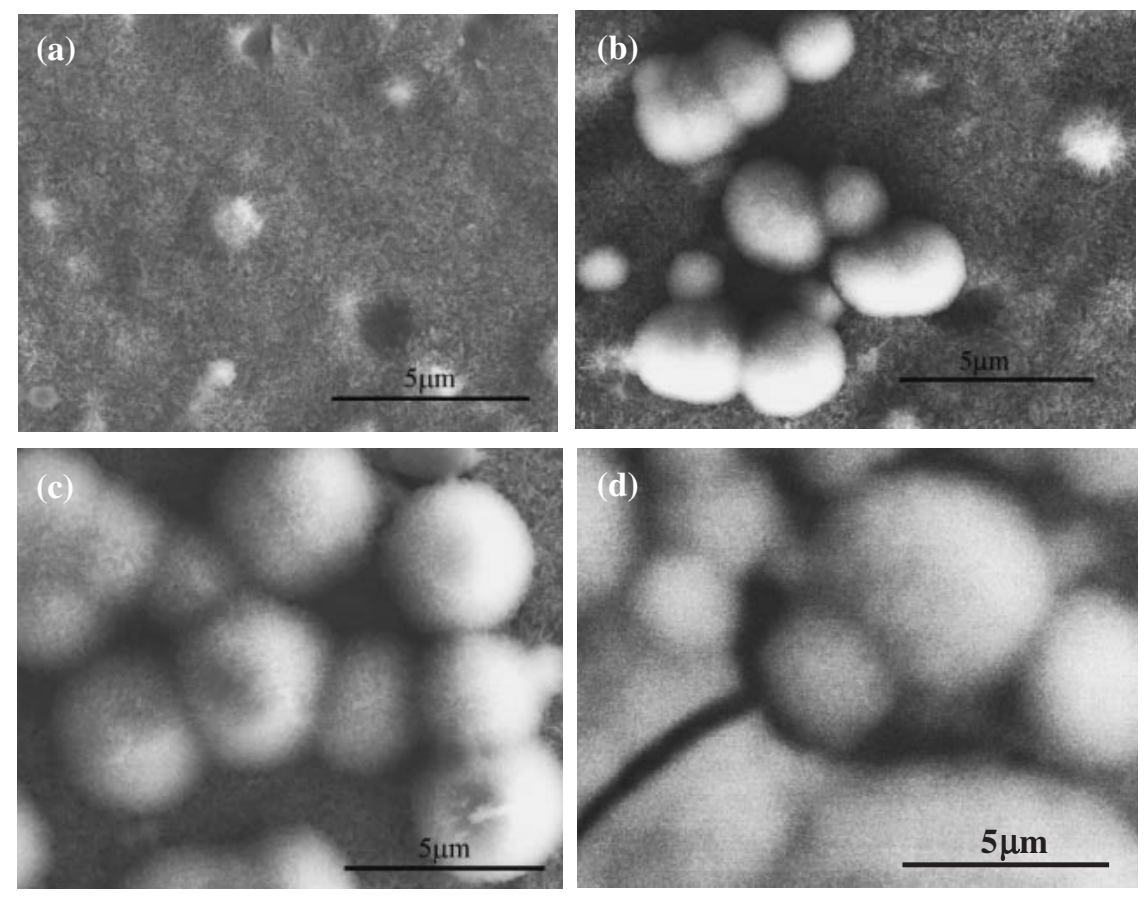

Fig. 6 Surface morphologies of alkali-treated Ti-coated $\mathrm{Ti}_{40} \mathrm{Zr}_{10} \mathrm{Cu}_{36} \mathrm{Pd}_{14} \mathrm{BMG}$ immersed in Hanks' solution for different days. (a) 1 day (b) 3 days (c) 6 days (d) 15 days.

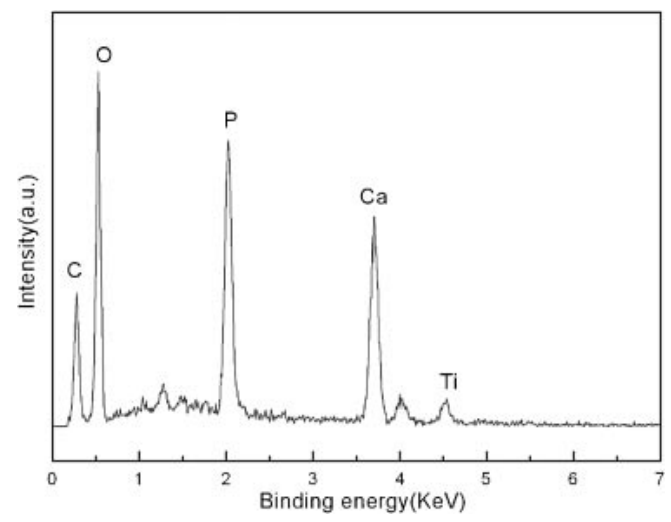

Fig. 7 EDS spectrum of alkali-treated Ti-coated $\mathrm{Ti}_{40} \mathrm{Zr}_{10} \mathrm{Cu}_{36} \mathrm{Pd}_{14} \mathrm{BMG}$ immersed in Hanks' solution for 15 days.

On the other hand, a porous sodium titanate reduced by the reactions between the Ti-coating and $\mathrm{OH}^{-}$ions ${ }^{8)}$ is found by SEM (Fig. 5) after alkali treatment. The surface of the Ticoated sample is partially dissolved by the attack of $\mathrm{OH}^{-}$and $\mathrm{HTiO}_{3}{ }^{-}$is formed, which reacts with $\mathrm{Na}$ to form sodium titanates such as $\mathrm{Na}_{2} \mathrm{Ti}_{5} \mathrm{O}_{11}$ or $\mathrm{Na}_{2} \mathrm{Ti}_{6} \mathrm{O}_{13}$. The porous sodium titanate then induces the formation of bone-like apatite in Hanks' solution. The $\mathrm{Ca} / \mathrm{P}$ ratio, calculated by EDS in Fig. 7, is about 1.67 after a 15 -day immersion, indicating the formation of stoichiometric hydroxyapatite. ${ }^{21)}$ In some cases, ${ }^{22,23)}$ some $\mathrm{Ca} / \mathrm{P}$ ratios of calcium phosphate layer formed by chemical treatment are located between $1.50 \sim 1.65$, which layer is calcium deficient apatite with carbonated $\mathrm{CO}_{3}{ }^{-2}$. The mechanism of apatite-formation in this research can be proposed as follows. When the alkali treatment samples are immersed in SBF, the sodium titanate layer releases $\mathrm{Na}^{+}$ions into the surrounding environment, exchanging with $\mathrm{H}_{3} \mathrm{O}^{+}$in the fluid to form Ti-OH groups on the surface, as early as $30 \mathrm{~min}$ after immersion. The Ti-OH group induces apatite nucleation by interacting with $\mathrm{Ca}$ and $\mathrm{P}$ ions. Once it forms, these apatite nuclei grow spontaneously by consuming the $\mathrm{Ca}$ and $\mathrm{P}$ ions in the surrounding environment, as shown in Fig. 6. The simple chemical treatment method is the most convenient method to improve bioactivity of Ti alloys, ${ }^{12)}$ in comparison with other hydroxyapatite surface modification technologies, such as plasma sputtering ${ }^{15)}$ and laser sputtering. ${ }^{19)}$ sputtering coating of hydroxyapatite exhibited relative poor adhesive strength with substrate. ${ }^{15,19)}$

Although the Ti-coating was bioactive, the adhesive strength between the coating and $\mathrm{Ti}_{40} \mathrm{Zr}_{10} \mathrm{Cu}_{36} \mathrm{Pd}_{14} \mathrm{BMG}$ substrate should be investigated in the future work. The surface coating could possibly reduce the tensile or fatigue strength of $\mathrm{Ti}_{40} \mathrm{Zr}_{10} \mathrm{Cu}_{36} \mathrm{Pd}_{14}$ BMG substrate, or cause galvanic corrosion once the coating is partially damaged through normal wear. In the future work, knowledge of mechanical properties of Ti-coated $\mathrm{Ti}_{40} \mathrm{Zr}_{10} \mathrm{Cu}_{36} \mathrm{Pd}_{14} \mathrm{BMG}$ will be especially necessary and important; those properties should be investigated to confirm the practical feasibility of Ti-coated $\mathrm{Ti}_{40} \mathrm{Zr}_{10} \mathrm{Cu}_{36} \mathrm{Pd}_{14} \mathrm{BMG}$ before the materials are used in real-life applications.

\section{Conclusions}

In this study, the formation of hydroxyapatite on uncoated $\mathrm{Ti}_{40} \mathrm{Zr}_{10} \mathrm{Cu}_{36} \mathrm{Pd}_{14}$ BMG and Ti-coated BMG was investigated. The results reveal that sodium titanate layer with a porous structure is formed on the surface of Ti-coat $\mathrm{Ti}_{40} \mathrm{Zr}_{10^{-}}$ $\mathrm{Cu}_{36} \mathrm{Pd}_{14} \mathrm{BMG}$ after an alkali treatment. Bone-like hydroxyapatite subsequently nucleates and proliferates on the porous sodium titanate formed on the Ti-coated $\mathrm{Ti}_{40} \mathrm{Zr}_{10} \mathrm{Cu}_{36} \mathrm{Pd}_{14}$ $\mathrm{BMG}$ in SBF. The hydroxyapatite cannot form directly on the surface of uncoated $\mathrm{Ti}_{40} \mathrm{Zr}_{10} \mathrm{Cu}_{36} \mathrm{Pd}_{14}$ BMG. 

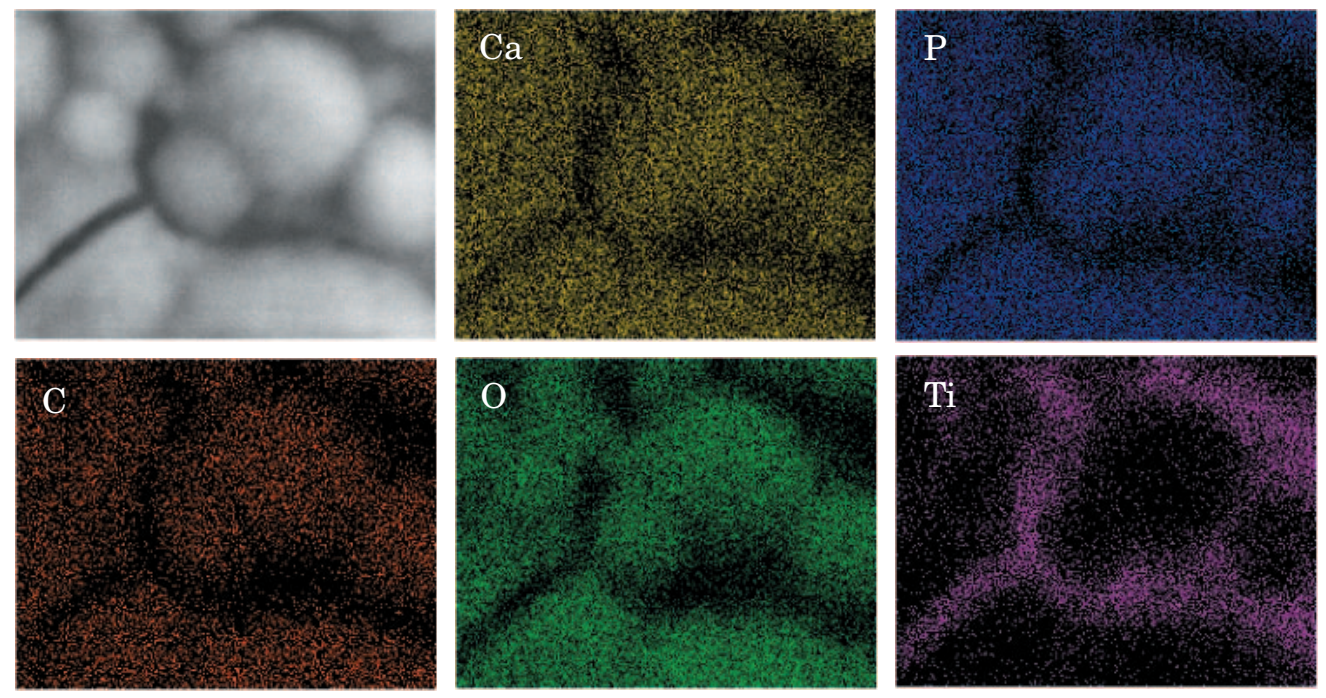

Fig. 8 SEM image and X-ray mappings of alkali-treated Ti-coated $\mathrm{Ti}_{40} \mathrm{Zr}_{10} \mathrm{Cu}_{36} \mathrm{Pd}_{14} \mathrm{BMG}$ immersed in Hanks' solution for 15 days.

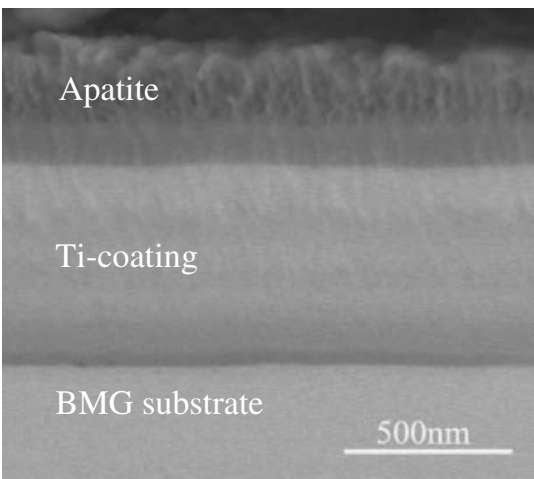

Fig. 9 SEM cross-section morphology of alkali-treated Ti-coated $\mathrm{Ti}_{40} \mathrm{Zr}_{10} \mathrm{Cu}_{36} \mathrm{Pd}_{14}$ BMG immersed in Hanks' solution for 15 days.

\section{Acknowledgments}

This work is financially supported by Research and Development Project on Advanced Metallic Glasses Inorganic Materials and Joining Technology, Institute for Materials Research, Tohoku University. The partial work was supported by "Nanotechnology Support Project" of the Ministry of Education, Culture, Sports, Science and Technology (MEXT), Japan.

\section{REFERENCES}

1) A. Inoue: Acta Mater. 48 (2000) 279-306.

2) S. L. Zhu, X. M. Wang, F. X. Qin and A. Inoue: Mater. Sci. Eng. A 459 (2007) 233-237.

3) F. X. Qin, M. Yoshimura, X. M. Wang, S. L. Zhu, A. Kawashima, K. Asami and A. Inoue: Mater. Trans. 48 (2007) 1855-1858.

4) F. X. Qin, X. M. Wang and A. Inoue: Intermetallics 15 (2007) 13371342.

5) P. C. Yashar and W. D. Sproul: Vacuum 55 (1999) 179-190.

6) H. Altun and S. Sen: Mater. Design 27 (2006) 1174-1179.

7) W. D. Sproul, M. E. Graham, M. S. Wong and P. J. Rudnik: Surf. Coat. Technol. 61 (1993) 139-143.

8) C. Liu, Q. Bi and A. Matthews: Surf. Coat. Tech. 163-164 (2003) 597-604.

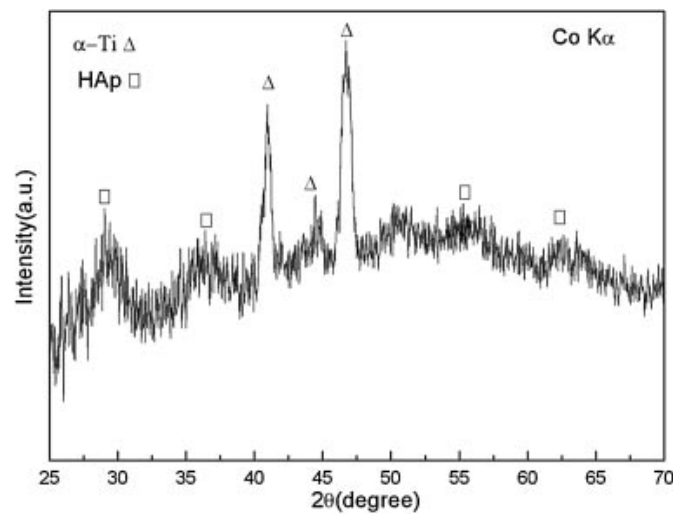

Fig. $10 \mathrm{XRD}$ pattern of the surface of Ti-coated $\mathrm{Ti}_{40} \mathrm{Zr}_{10} \mathrm{Cu}_{36} \mathrm{Pd}_{14} \mathrm{BMG}$ immersion in Hanks' solution for 15 days.

9) F. X. Qin, X. M. Wang and A. Inoue: Intermetallics 16 (2008) 917-922.

10) B. H. Lee, Y. D. Kim and K. H. Lee: Biomaterials 24 (2003) $2257-$ 2266.

11) H. M. Kim, F. Miyaji, T. Kokubo and T. Nakamura: J. Mater. Sci. Mater. Med. 7 (1997) 341-347.

12) T. Kokubo, F. Miyaji, H. M. Kim and T. Nakamura: J. Am. Ceram. Sco. 79 (1996) 1127-1129.

13) O. Grasmann and R. B. Heimann: J. Biomed. Mater. Res. B 53 (2000) 685-693.

14) H. C. Gledhill, I. G. Turner and C. Doyle: Biomaterials 22 (2001) 695700.

15) P. Duchyene, W. van Raemdonck, J. C. Heughbaert and M. Heughbaert: Biomaterials 7 (1986) 97-103.

16) T. Kasuga, H. Kondo and M. Nogami: J. Cryst. Growth. 235 (2002) 235-240.

17) H. W. Kim, Y. H. Koh, L. H. Li, S. Lee and H. E. Kim: Biomaterials 25 (2004) 2533-2538.

18) L. A. Sena, M. C. Andrade, A. M. Rossi and G. S. Almeida: J. Biomed. Mater. Res. A 60 (2002) 1-7.

19) S. Ban and S. Maruno: Biomaterials 16 (1995) 977-981.

20) M. Uchida, H. M. Kim, F. Miyaji, T. Kokubo and T. Nakamura: Biomaterials 23 (2002) 313-317.

21) C. E. Wen, W. Xu, W. Y. Hu and P. D. Hodgson: Acta Biomater. 3 (2007) 403-410.

22) C. Y. Zeng, S. J. Li, X. J. Tao, Y. L. Hao, R. Yang and L. Zhang: Mater. Sci. Eng. C 27 (2007) 824-831.

23) A. C. Tas and S. B. Bhaduri: J. Mater. Res. 19 (2004) 2742-2749. 